\title{
Effects of Calcium and Magnesium on Plant Growth, Biomass Partitioning, and Fruit Yield of Winter Greenhouse Tomato
}

\author{
Xiuming Hao and Athanasios P. Papadopoulos
}

Agriculture andAgri-Food Canada, Greenhouse and Processing Crops Research Centre, Harrow, Ontario, Canada NOR 1GO

Additional index words. Lycopersicon esculentum, biomass distribution, blossom-end rot, rockwool

\begin{abstract}
Tomato (Lycopersicon esculentum Mill) 'Trust' was grown on rockwool with nutrient solutions containing two levels of calcium (150 and $\left.300 \mathrm{mg} \cdot \mathrm{L}^{-1}\right)$ in factorial combination with three levels of magnesium $\left(20,50\right.$, and $\left.80 \mathrm{mg} \cdot \mathrm{L}^{-1}\right)$ in Winters 1997 and 1998, to investigate the effects of calcium and magnesium on growth, biomass partitioning, and fruit production. Plants grown at $20 \mathrm{mg} \cdot \mathrm{L}^{-1} \mathrm{Mg}$ started to show $\mathrm{Mg}$ deficiency symptoms (leaf chlorosis) at 8 weeks after planting. The chlorophyll content of middle and bottom leaves increased with increasing $\mathrm{Mg}$ concentration in the nutrient solution. At $300 \mathrm{mg} \cdot \mathrm{L}^{-1} \mathrm{Ca}$, total fruit yield and fruit dry matter increased linearly with increasing Mg concentration; marketable fruit yield and total plant biomass showed similar response but to a lower degree. At $150 \mathrm{mg} \cdot \mathrm{L}^{-1} \mathrm{Ca}$, total plant biomass, fruit dry matter and yield peaked at $50 \mathrm{mg} \cdot \mathrm{L}^{-1} \mathrm{Mg}$. The biomass allocation to fruit increased while allocation to leaves decreased with increasing Mg concentration. The Mg effects on total and marketable fruit yield were mainly due to its influence on fruit yield in the late growth stage. Incidence of blossom-end rot (BER) at $150 \mathrm{mg} \cdot \mathrm{L}^{-1} \mathrm{Ca}$ increased linearly with increasing Mg concentration while it was not affected by $\mathrm{Mg}$ concentration at $300 \mathrm{mg} \cdot \mathrm{L}^{-1} \mathrm{Ca}$. For a winter greenhouse tomato crop, the appropriate $\mathrm{Ca}$ and $\mathrm{Mg}$ concentrations for tomato production appear to be at 300 and $80 \mathrm{mg} \cdot \mathrm{L}^{-1}$, respectively.
\end{abstract}

Greenhouse tomato production and consumption in North America has increased substantially in the last few years. The share of greenhouse tomato in the fresh tomato market has increased from $1 \%$ in 1990 to $16 \%$ today (DeGiglio, 2003). In North America, almost all the greenhouse tomatoes are produced with a soilless culture system, mostly on rockwool Rockwool releases little or no mineral nutrients and has a very low buffering capacity. Precise management of plant nutrition has a much larger influence on greenhouse tomato production in rockwool than on soil-based tomato production systems.

Effects of calcium $(\mathrm{Ca})$ nutrition on growth, fruit yield and quality of greenhouse tomato have been investigated extensively in northern Europe (Ho et al., 1999). Leaf Ca deficiency in tomato reduces leaf size, and causes necrosis of young leaves and yield loss in extreme cases (Adams and Gizaway, 1988; Adams and Holder, 1992; Holder and Cockshull, 1990). Low supply of calcium to tomato fruit leads to more fruit with blossom-end rot (BER) (Ho et al., 1999; Saure, 2001). Excessive supply of calcium to fruit causes goldspeck/goldspot, cells containing a granular mass of tiny calcium oxalate crystals (De Kreij et al., 1992; Den Outer and van Veenendaal, 1988; Ho et

Received for publication3 Sept. 2002. Accepted fo publication 29 Sept. 2003. Use of trade names in this publication does not imply endorsement of products by Agriculture and Agri-Food Canada nor criticism of similar ones not mentioned. This research was funded, in part, by the Ontario Greenhouse Vegetable Growers. We thank A. Mosca and J. Blackburn for invaluable technical support. al., 1999), which not only affects the appearance of the fruit, but also reduces its shelf life (Janse, 1988)

Magnesium (Mg) deficiency occurs regularly in greenhouse tomatoes (Ontario Ministry of Agriculture and Food, 2001). Because the deficiency symptoms, usually in the main spring crop, occur on the oldest (bottom) less productive leaves, this has not been seen as a major problem. However, in fall or winter tomato crops, the deficiency may occur in the middle leaves, which could have significant influence on plant productivity (Sonneveld and Voogt, 1991). This reduction in plant productivity could be due to reduced biomass production (from low leaf photosynthesis) alone, or due to both a reduced overall biomass production and a lower biomass allocation to fruit. Information on the effects of mineral nutrients on biomass partitioning is useful for clarifying the mechanisms of their influence on fruit yield and is valuable for developing tomato growth models (Marcelis et al., 1998). There has been limited or no information available on the effects of $\mathrm{Ca}$ and $\mathrm{Mg}$ concentrations in the nutrient solution on biomass partitioning in greenhouse tomatoes.

Most of the information on $\mathrm{Ca}$ and $\mathrm{Mg}$ nutrition of greenhouse tomatoes is derived from research conducted in northern Europe; little such research has been done in North America. Past research (Adams, 1994; Ho et al., 1999; Papadopoulos and Hao, 2002; Sonneveld, 1987; Sonneveld and Voogt, 1991) has shown that the optimum levels of $\mathrm{Ca}$ and $\mathrm{Mg}$ for greenhouse tomatoes are strongly affected by climatic conditions such as solar irradiance, humidity and temperature. Leamington $\left(41^{\circ} \mathrm{N}\right.$, continental climatic type) in Ontario, Canada, where one-third of North America greenhouse tomatoes are grown, has quite different climatic conditions from northern Europe (close to 50 ${ }^{\circ} \mathrm{N}$, maritime climatic type). Therefore, there is a need to conduct experiments in this area for optimizing $\mathrm{Ca}$ and $\mathrm{Mg}$ nutrition. Furthermore, in a previous study designed to develop closed cultivation systems in Ontario, it appeared that high levels of $\mathrm{Ca}$ and $\mathrm{Mg}$ caused by accumulation in closed hydroponic systems may had been beneficial to tomato growth (Hao and Papadopoulos, 2002). This suggested that the standard recommendations for the $\mathrm{Ca}$ and $\mathrm{Mg}$ nutrition of greenhouse tomatoes in Ontario (Papadopoulos, 1991) might need adjustment. This study was undertaken to investigate the effects of $\mathrm{Ca}$ and $\mathrm{Mg}$, and their interactions, on plant growth, biomass partitioning, and fruit yield for optimizing the mineral nutrition of greenhouse tomato grown in winter.

\section{Materials and Methods}

Two winter experiments were conducted at the Greenhouse and Processing Crops Research Centre, (GPCRC), Agriculture and Agri-Food Canada, Harrow $\left(41^{\circ} \mathrm{N}\right)$, Ontario, Canada. The experiments were conducted in two double-inflated polyethylene greenhouses (45 $\mathrm{m}^{2}$ each) from September 1997 to January 1998, and from September 1998 to January 1999, respectively.

'Trust' tomato seeds were sown in small rockwool cubes $(3.8 \times 3.6 \times 4.0 \mathrm{~cm}$, Pargro Inc., Orillia, Ont., Canada) in seedling packs. After cotyledons became fully unfolded, the seedlings were transplanted into large rockwool blocks $(7.5 \times 7.5 \times 7.5 \mathrm{~cm}$; Pargro Inc., Orillia, Ont., Canada). The transplants were raised on benches and flood irrigated using a Harrow Fertigation Manager (Climate Control Systems Inc., Leamington, Ontario, Canada) according to standard nutrient recommendations (Papadopoulos, 1991; Papadopoulos and Liburdi, 1989)

On 11 Sept. 1997 and 18 Sept. 1998, at the four- to five-leaf stage, transplants were transferred onto sleeved rockwool slabs $(90 \times 15 \times$ $7.5 \mathrm{~cm}$, Pargro Inc., Orillia, Ont., Canada) in the greenhouses, at a 3 plants $\mathrm{m}^{-2}$ plant population. Day/night heating temperature was set at $19 / 18^{\circ} \mathrm{C}$ while ventilation temperature was set at $23^{\circ} \mathrm{C}$. Day/night relative humidity was set at $70 \% / 65 \%$. Plants were trained to a single stem according to commercial practices. An electrical vibrator was used to assist flower pollination daily. The plants were drip-irrigated with appropriate nutrient solutions. To avoid nutrient buildups in the rockwool, $20 \%$ to $30 \%$ extra nutrient solution was applied (Papadopoulos, 1991). The plants were topped on 1 Dec. 1997, and 3 Dec. 3 1998, respectively.

Nutrient treatments. In both experiments, six nutrient treatments were applied as a factorial combination of two Ca concentrations (150 and $300 \mathrm{mg} \cdot \mathrm{L}^{-1}$ ) and three $\mathrm{Mg}$ concentrations $\left(20,50\right.$, and $\left.80 \mathrm{mg} \cdot \mathrm{L}^{-1}\right)$. In each polyethylene greenhouse, 8 rows of plants were grown. Two side rows were used as guard rows while the 
other six rows were used as treatment rows. There were nine plants in each treatment row (plot). The plant at either end of the treatment row was treated as a guard plant. Therefore, data were only collected from seven plants in each plot. The treatments were replicated four times over 2 years. Each treatment plot was fed with an independent irrigation system.

Nitrogen $\left(185 \mathrm{mg} \cdot \mathrm{L}^{-1} \mathrm{NO}_{3}-\mathrm{N}\right.$ and $15 \mathrm{mg} \cdot \mathrm{L}^{-1}$ $\left.\mathrm{NH}_{4}-\mathrm{N}\right)$, phosphorus $\left(50 \mathrm{mg} \cdot \mathrm{L}^{-1}\right)$, potassium $\left(390 \mathrm{mg} \cdot \mathrm{L}^{-1}\right)$, iron $\left(7 \mathrm{mg} \cdot \mathrm{L}^{-1}\right)$, manganese $\left(0.8 \mathrm{mg} \cdot \mathrm{L}^{-1}\right)$, zinc $\left(0.16 \mathrm{mg} \cdot \mathrm{L}^{-1}\right)$, copper $(0.05$ $\left.\mathrm{mg} \cdot \mathrm{L}^{-1}\right)$ and boron $\left(0.52 \mathrm{mg} \cdot \mathrm{L}^{-1}\right)$ were used in all nutrient treatments. To equalize the $\mathrm{EC}$ of nutrient solution across treatments (to avoid confounding the effects of $\mathrm{Ca}$ and $\mathrm{Mg}$ with $\mathrm{EC}$ ), the concentration of chloride $\left(\mathrm{Cl}^{-}\right)$, sulphate $\left(\mathrm{SO}_{4}^{2-}\right)$ and sodium $\left(\mathrm{Na}^{+}\right)$were allowed to vary in the range of 100 to $150 \mathrm{mg} \cdot \mathrm{L}^{-1}, 280$ to $450 \mathrm{mg} \cdot \mathrm{L}^{-1}$, and 40 to $80 \mathrm{mg} \cdot \mathrm{L}^{-1}$, respectively. The variation of $\mathrm{Cl}^{-}, \mathrm{SO}_{4}^{2-}$ and $\mathrm{Na}^{+}$within those ranges of concentration does not have any significant effect on greenhouse tomatoes (Lopez et al., 1996; Nukaya and Hashimoto, 2000; Voogt and Sonneveld, 1997). The final $\mathrm{EC}$ for all the nutrient treatments was $3 \pm 0.2$ $\mathrm{mS} \cdot \mathrm{cm}^{-1}$ while the $\mathrm{pH}$ was adjusted to 5.8 by adding nitric acid.

Leaf chlorophyll, plant growth, and biomass. Plant leaf dry weight, and stem dry weight were measured at the end of the experiment. All leaves removed from the plants during the experiments were saved, and their dry weights measured and recorded. Fruit dry matter content was assessed monthly, and unharvested fruit dry matter content was determined at the end of the experiments. Each time, five to six fruit were sampled from each plot. Fruit dry weight was determined after drying at $65{ }^{\circ} \mathrm{C}$ for 3 weeks. The plant leaf dry weight, stem dry weight data plus the data on yield and fruit dry matter content were used to estimate biomass partitioning. Leaf chlorophyll was estimated with a SPAD-502 leaf chlorophyll meter (Minota, Osaka, Japan) on the $5^{\text {th }}, 10^{\text {th }}$, $15^{\text {th }}, 20^{\text {th }}$, and $25^{\text {th }}$ leaf (counted from the top leaf longer than $10 \mathrm{~cm}$ ). Leaf $\mathrm{Mg}$ and Ca deficiency symptoms were monitored weekly. The date of the first appearance of symptoms and a visual estimate of the percentage of leaf area with the symptoms were recorded.

Fruit harvest and grading. Fruit reaching breaker stage were harvested two to three times a week from 13 Nov. 1997 to 26 Jan. 1998 and from 19 Nov. 1998 to 18 Jan. 1999. Harvested fruit were graded according to commercial grading standards (Ontario Ministry of Agriculture and Food, Regulation 378/90, 1987). Unmarketable fruit were divided into blossom-end rot (BER) and catfaced (CF) and other unmarketable.

Data analysis. Data were analysed with the SAS General Linear Model Procedure (GLM). The data from the 2 years were combined before analysis of variance was conducted. If the treatment effects were significant in the analysis of variance, then their means were separated with Duncan's multiple-range test. A polynomial model was used for regression analysis on $\mathrm{Mg}$ concentrations when the $P$ value for the $\mathrm{Mg}$ effect in the analysis of variance was $<0.20$. The regression model was fitted with a backward elimination method and $P$ value of 0.15 was used to decide whether a model term should be dropped from the model during the fitting process. The partial $R^{2}\left(R_{\mathrm{Mg}}^{2}\right)$, which measured the strength of the relationship between the response variable and $\mathrm{Mg}$ concentration after adjustment for $\mathrm{CA}$ and replication (block) effects, was calculated for the final regression. Significance of the $R^{2}$ was determined by an F test (Hao, 1995): $\mathrm{F}$ $=\left(\left(R_{\mathrm{Mg}}^{2}\right)((\right.$ error $-\mathrm{df})) /\left(\left(1-R_{\mathrm{Mg}}^{2}\right)(\mathrm{Mg}-\mathrm{df})\right.$ with $\mathrm{Mg}-\mathrm{df}$, error - df, where $\mathrm{Mg}-\mathrm{df}$ was the degrees of freedom for all $\mathrm{Mg}$ terms, and error-df was the degrees of freedom for error. Only the final regression functions that were significant $(P<0.05)$ are reported.

\section{Results and Discussion}

Plant growth and leaf chlorosis. Plants started to show symptoms of $\mathrm{Mg}$ deficiency (leaf chlorosis) 8 weeks after planting, when the plants were $\approx 1.5 \mathrm{~m}$ in height in the two experiments. Treatment 300/20 (Ca/Mg $\mathrm{mg} \cdot \mathrm{L}^{-1}$ ) showed first and most severe $\mathrm{Mg}$ deficiency symptoms (Table 1). Treatments $150 / 50,150 / 80,300 / 80(\mathrm{Ca} / \mathrm{Mg})$ showed little or no symptoms of $\mathrm{Mg}$ deficiency. There were no visible leaf Ca-deficiency symptoms in the two experiments.

The Mg-deficiency symptoms appeared not only on bottom leaves (Table 1), but also on the top and middle leaves. In contrast to common opinion, the most severe $\mathrm{Mg}$ deficiency symptoms occurred on the upper middle leaves instead of the bottom leaves. The

Table 1. Leaf greenness of tomato plants grown at different $\mathrm{Ca}$ and $\mathrm{Mg}$ concentrations in 1998-99. Leaf greenness was measured with a SPAD 502 leaf chlorophyll meter on 4 Nov., 7 Dec., and 21 Dec., 1998 and 6 Jan. 1999 for leaf 5, 10, 15, 20, and 25. Leaf position was counted from the top leaf longer than $10 \mathrm{~cm}$. There was no significant difference $(P>0.15)$ among treatments on 4 Nov.and for leaf 25 in all the measurements. The data presented are means of three plants. Means followed by different letters are significantly different $(P<0.05)$.

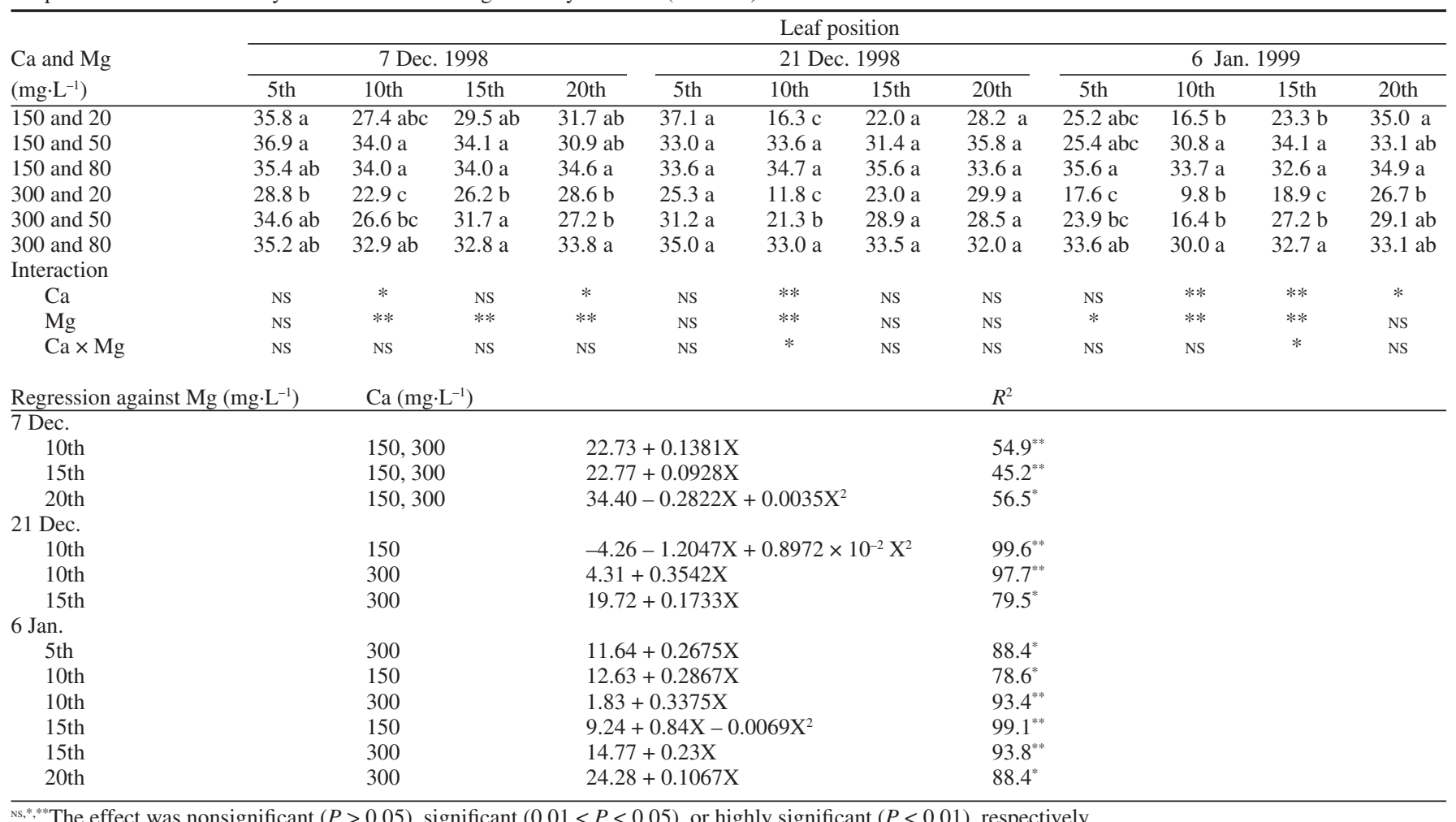

HortScience Vol. 39(3) June 2004 
Table 2. Biomass and biomass partitioning of tomato grown at different $\mathrm{Ca}$ and $\mathrm{Mg}$ concentrations in 1997 and 1998 . The means presented are averages of 2 year data. Means followed by different letters are significantly different $(P<0.05)$. The $P$ value for $\mathrm{Mg}$ effect on biomass and biomass allocation to fruit $(\%)$ was 0.07 and 0.09 , respectively.

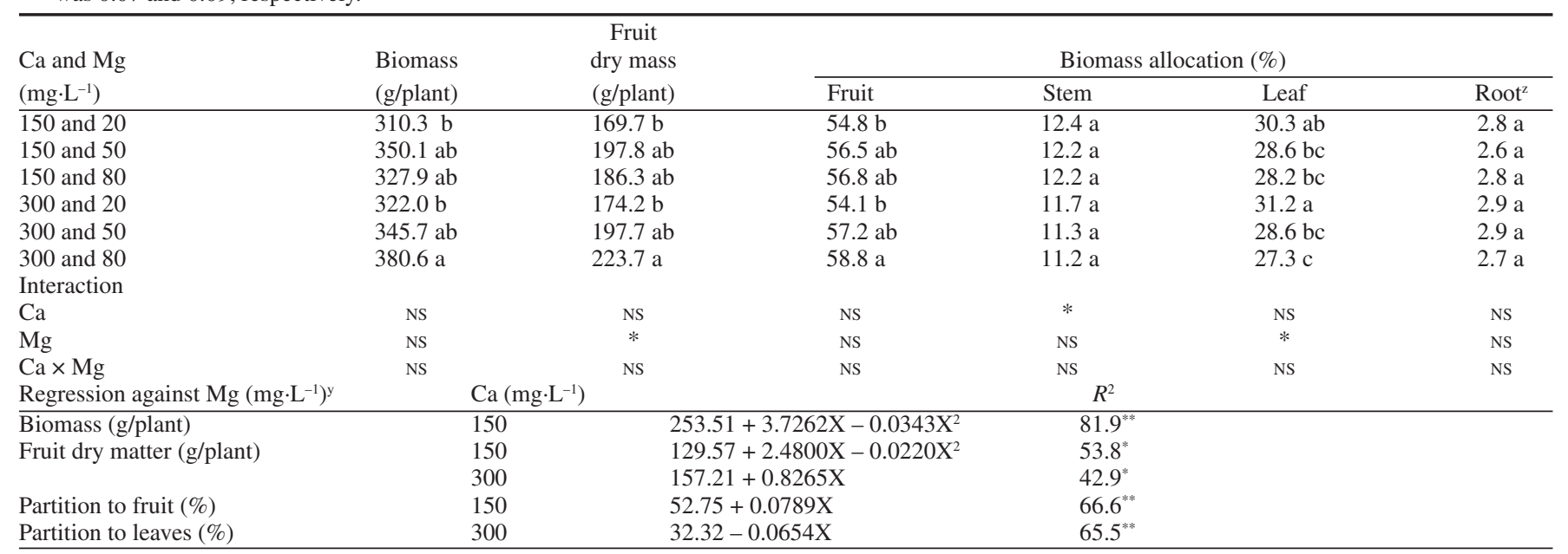

${ }^{2}$ Collectable roots from the underside of the rockwool slabs.

'The regression of biomass on $\mathrm{Mg}$ concentration at $300 \mathrm{mg} \cdot \mathrm{L}^{-1} \mathrm{Ca}$ was $293.78+0.9757 \mathrm{X}$ with a $P$ value $=0.077$.

ws,*,**The effect was nonsignificant $(P>0.05)$, significant $(0.01<P<0.05)$, or highly significant $(P<0.01)$, respectively.

Table 3. Fruit yield, size and blossom-end rot (BER) of tomato grown at different Ca and Mg concentrations in 1997 and 1998. The means presented are averages of 2 year data. Means followed by different letters are significantly different $(P<0.05)$. The $P$ value for the $\mathrm{Mg}$ effect on total fruit weight was 0.07 . The $P$ value for the $\mathrm{Ca}$ effect on marketable yield was 0.1

\begin{tabular}{|c|c|c|c|c|c|}
\hline $\begin{array}{l}\mathrm{Ca} \text { and } \mathrm{Mg} \\
\left(\mathrm{mg} \cdot \mathrm{L}^{-1}\right)\end{array}$ & $\begin{array}{c}\text { Total } \\
\text { fruit } \\
\text { wt } \\
\text { (kg/plant) }\end{array}$ & $\begin{array}{c}\text { Marketable } \\
\text { yield } \\
\text { (kg/plant) }\end{array}$ & $\begin{array}{c}\text { Marketable } \\
\text { fruit } \\
\text { size } \\
\text { (g/fruit) }\end{array}$ & $\begin{array}{c}\text { Marketable }^{z} \\
\text { fruit } \\
\text { wt (\%) }\end{array}$ & $\begin{array}{c}\mathrm{BER}^{\mathrm{z}} \\
\text { fruit } \\
\text { wt (\%) }\end{array}$ \\
\hline 150 and 50 & $4.13 \mathrm{ab}$ & $3.77 \mathrm{ab}$ & $130.4 \mathrm{a}$ & $91.2 \mathrm{bc}$ & $4.73 \mathrm{~b}$ \\
\hline 150 and 80 & $3.88 \mathrm{ab}$ & $3.47 \mathrm{~b}$ & $126.8 \mathrm{a}$ & $89.3 \mathrm{c}$ & $7.12 \mathrm{a}$ \\
\hline 300 and 20 & $3.69 \mathrm{~b}$ & $3.53 \mathrm{~b}$ & $128.5 \mathrm{a}$ & $95.5 \mathrm{ab}$ & $0.83 \mathrm{c}$ \\
\hline 300 and 50 & $4.01 \mathrm{ab}$ & $3.91 \mathrm{ab}$ & $125.4 \mathrm{a}$ & $97.4 \mathrm{a}$ & $0.50 \mathrm{c}$ \\
\hline $\mathrm{Ca}$ & NS & NS & NS & $* *$ & $* *$ \\
\hline $\mathrm{Mg}$ & NS & NS & NS & NS & NS \\
\hline $\mathrm{Ca} \times \mathrm{Mg}$ & NS & NS & NS & NS & NS \\
\hline Regression against $\mathrm{Mg}\left(\mathrm{mg} \cdot \mathrm{L}^{-1}\right)^{\mathrm{y}}$ & $\mathrm{Ca}\left(\mathrm{mg} \cdot \mathrm{L}^{-1}\right)$ & & & $R^{2}$ & \\
\hline \multirow[t]{2}{*}{ Total fruit weight $\left(\mathrm{kg} \mathrm{plant}^{-1}\right)$} & 150 & \multicolumn{2}{|c|}{$2829.83+45.6185 X-0.4160 X^{2}$} & $47.3^{*}$ & \\
\hline & 300 & \multicolumn{2}{|c|}{$3429.82+12.3501 X$} & $45.5^{*}$ & \\
\hline
\end{tabular}

${ }^{2}$ Percentage over total fruit weight.

y The regression of marketable yield on $\mathrm{Mg}$ concentration, at $300 \mathrm{mg} \cdot \mathrm{L}^{-1} \mathrm{Ca}$ was $3310.81+11.6106 \mathrm{X}$ with a p-value $=0.07$.

Ns,****The effect was nonsignificant $(P>0.05)$, significant $(0.01<P<0.05)$, or highly significant $(P<0.01)$, respectively.

chlorophyll of the $10^{\text {th }}$ and $15^{\text {th }}$ fully expanded leaf, at middle to late growth stages, increased with increasing $\mathrm{Mg}$ concentration (Table 1), especially at $300 \mathrm{mg} \cdot \mathrm{L}^{-1} \mathrm{Ca}$. The occurrence of $\mathrm{Mg}$ deficiency on the middle leaves was also found by Sonneveld and Voogt (1991) in a fall greenhouse tomato crop. In this study, even at $50 \mathrm{mg} \cdot \mathrm{L}^{-1} \mathrm{Mg}$ (the recommended $\mathrm{Mg}$ level, Papadopoulos, 1991), the chlorophyll content of the $10^{\text {th }}$ fully expanded leaf was significantly lower than at $80 \mathrm{mg} \cdot \mathrm{L}^{-1}$ when Ca was applied at $300 \mathrm{mg} \cdot \mathrm{L}^{-1}$ (Table 1). The occurrence of Mg-deficiency symptoms on the upper-middle leaves could significantly affect the photoassimilate production and supply to other parts of the plants.

There was a significant interaction between $\mathrm{Ca}$ and $\mathrm{Mg}$ on the chlorophyll content of the $10^{\text {th }}$ fully expanded leaf on 21 Dec. 1998 and 6 Jan. 1999 (Table 1). High Ca (300 mg.L $\left.\mathrm{L}^{-1}\right)$ increased the probability of leaf chlorosis (Table 1), most likely through its competition with Mg for uptake, which was reflected by a stronger response of the leaf chlorophyll loss to low $\mathrm{Mg}$ concentrations at $300 \mathrm{mg} \cdot \mathrm{L}^{-1} \mathrm{Ca}$. The antagonism between $\mathrm{Ca}$ and $\mathrm{Mg}$ for uptake in tomato is well known (Ho et al., 1999; Paiva et al., 1998).

Biomass and biomass partitioning. At 300 $\mathrm{mg} \cdot \mathrm{L}^{-1} \mathrm{Ca}$, total fruit dry matter increased linearly with increasing $\mathrm{Mg}$ concentration while biomass partitioned to leaves decreased linearly with increasing Mg concentration (Table 2). Total plant biomass at $300 \mathrm{mg} \cdot \mathrm{L}^{-1} \mathrm{Ca}$ also increased with increasing $\mathrm{Mg}$ concentration as total fruit dry matter but in a smaller magnitude. Presumably the increase in biomass partitioned to fruit indicated a higher leaf photosynthetic capability and higher export of carbohydrates from leaves (per unit weight) at high Mg concentration. At
$150 \mathrm{mg} \cdot \mathrm{L}^{-1} \mathrm{Ca}$, total biomass and total fruit dry matter production were the highest at $50 \mathrm{mg} \cdot \mathrm{L}^{-1}$ $\mathrm{Mg}$, and the percent of the biomass partitioned to fruit also increased linearly with increasing $\mathrm{Mg}$ concentration. High Ca $\left(300 \mathrm{mg} \cdot \mathrm{L}^{-1}\right)$ reduced biomass partitioning to the stem.

Fruit yield and grades. Total and marketable yield at $20 \mathrm{mg} \cdot \mathrm{L}^{-1} \mathrm{Mg}$ was lowest regardless of Ca concentration (Table 3). Marketable yield at $150 / 80 \mathrm{mg} \cdot \mathrm{L}^{-1} \mathrm{Ca} / \mathrm{Mg}$ was reduced due to a high BER incidence. At $300 \mathrm{mg} \cdot \mathrm{L}^{-1} \mathrm{Ca}$, total fruit weight increased linearly with increasing $\mathrm{Mg}$ concentration while it showed a quadratic response to $\mathrm{Mg}$ concentration at $150 \mathrm{mg} \cdot \mathrm{L}^{-1}$ Ca. At $150 \mathrm{mg} \cdot \mathrm{L}^{-1} \mathrm{Ca}$, total fruit weight was the highest at $50 \mathrm{mg} \cdot \mathrm{L}^{-1} \mathrm{Mg}$. Marketable fruit yield showed similar but weaker response. The percentage of BER fruit increased linearly with increasing $\mathrm{Mg}$ concentration at $150 \mathrm{mg} \cdot \mathrm{L}^{-1} \mathrm{Ca}$ while it was not affected by $\mathrm{Mg}$ concentration 

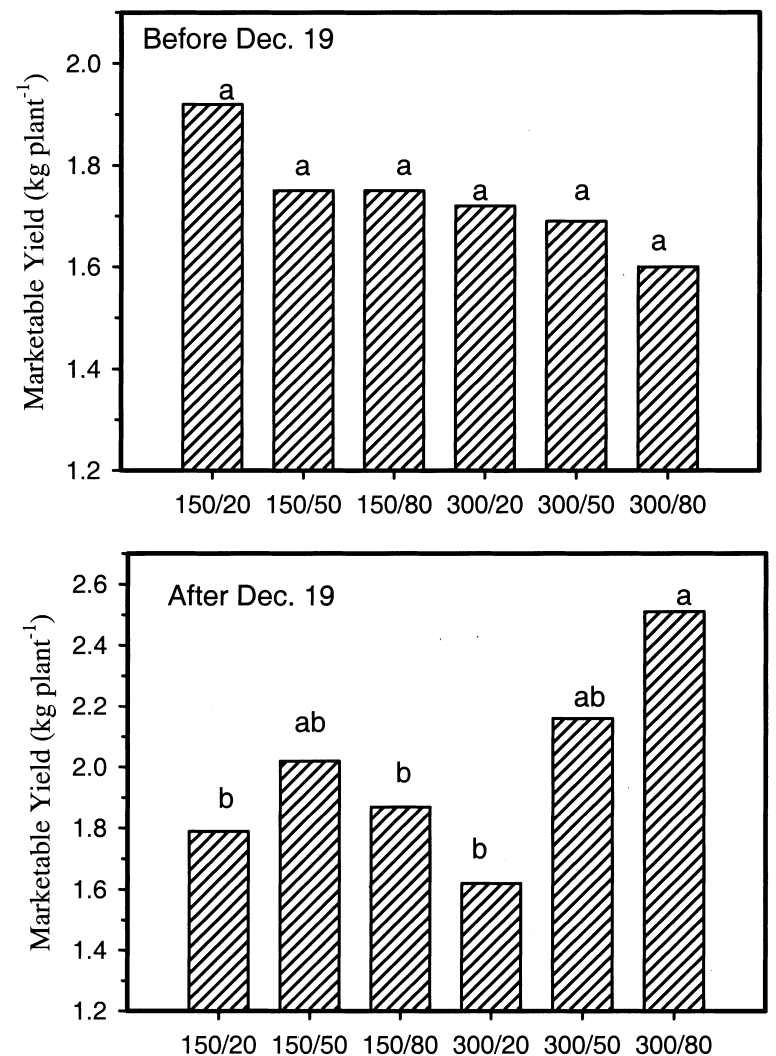

$\mathrm{Ca}$ and $\mathrm{Mg}$ concentrations, $\mathrm{mg} \mathrm{L}^{-1}$ ary 1999, respectively. It usually takes 6 to 8 weeks from fruit set to ripening in greenhouse tomato. Therefore, the fruit harvested in the first month developed under much stronger solar radiation than those harvested in the second month. Magnesium is a major component of chlorophyll, which is critical for the light reaction of photosynthesis. Under limiting light conditions, such as those in the last 2 months of our experiments, reduction of light reaction efficiency with low chlorophyll caused by low $\mathrm{Mg}$ concentration could have significantly reduced the photo-assimilate production, and thus caused a concomitant yield reduction. In a study conducted on a fall greenhouse crop on rockwool, Sonneveld found (1987) that root $\mathrm{Mg}$ uptake capability of tomato roots declined as the plant aged. This indicates that the supply of $\mathrm{Mg}$ to tomato plants may need to be increased towards late growth stages. For both above discussed reasons, it would appear appropriate that the supply of $\mathrm{Mg}$ in a winter tomato crop be increased towards the latest growth stages.

In conclusion, high $\mathrm{Ca}\left(300 \mathrm{mg} \cdot \mathrm{L}^{-1}\right) \mathrm{re}-$

Fig. 1. Monthly marketable fruit yield at different $\mathrm{Ca}$ and $\mathrm{Mg}\left(\mathrm{mg} \cdot \mathrm{L}^{-1}\right)$ concentrations in 1997 and 1998. The different letters above the bars indicate a significant difference $(P<0.05)$; Duncan's multiple range test.

at $300 \mathrm{mg} \cdot \mathrm{L}^{-1} \mathrm{Ca}$. The increase in BER with high $\mathrm{Mg}$ at $150 \mathrm{ppm} \mathrm{Ca}$ resulted in a linear reduction in the percentage of marketable fruit, and a significantly lower marketable fruit yield at $150 / 80 \mathrm{mg} \cdot \mathrm{L}^{-1} \mathrm{Ca} / \mathrm{Mg}$ than at $300 / 80 \mathrm{mg} \cdot \mathrm{L}^{-1} \mathrm{Ca} / \mathrm{Mg}$. The BER incidence at $300 \mathrm{mg} \cdot \mathrm{L}^{-1} \mathrm{Ca}$, at all $\mathrm{Mg}$ treatments, was quite low. High Ca reduced the BER incidence and increased the percentage of marketable fruit. There was no significant $\mathrm{Ca}$ or $\mathrm{Mg}$ effect on marketable fruit size and fruit distribution in other grades (Table 3).

High $\mathrm{Mg}$ concentration did not offer any advantage over low $\mathrm{Mg}$ concentration in early fruit production (Fig.1). There was no significant difference in the marketable yield from the first month of fruit harvest (before Dec. 19) among various $\mathrm{Mg}$ concentrations regardless of Ca concentration. However, the marketable yield in the second month (after 19 Dec.) of fruit harvest significantly increased with $\mathrm{Mg}$ concentration at the $300 \mathrm{mg} \cdot \mathrm{L}^{-1}$ of $\mathrm{Ca}$. The difference in response to $\mathrm{Mg}$ concentration might be due to two factors: light and plant physiological age. Monthly average daily solar radiation during the 1997 experiment was 14.6, $11.8,5.4,4.2$, and $4.3 \mathrm{MJ} \cdot \mathrm{m}^{-2} \cdot \mathrm{d}^{-1}$ for September 1997 to January 1998, respectively. The monthly average daily solar radiation during the 1998 experiment was $16.8,10.4,6.4,5.8$, and $6.1 \mathrm{MJ} \cdot \mathrm{m}^{-2} \cdot \mathrm{d}^{-1}$ for September 1998 to Januduced the BER incidence. Low Mg (20 ppm) reduced leaf chlorophyll in middle leaves and reduced fruit yield in late fruit production. Fruit biomass and total fruit yield increased linearly with increasing $\mathrm{Mg}$ concentration at $300 \mathrm{mg} \cdot \mathrm{L}^{-1} \mathrm{Ca}$. Total plant biomass and marketable fruit yield at $300 \mathrm{mg} \cdot \mathrm{L}^{-1} \mathrm{Ca}$ showed similar but weaker response. At $150 \mathrm{mg} \cdot \mathrm{L}^{-1}$ $\mathrm{Ca}$, total plant biomass and fruit yield peaked at $50 \mathrm{mg} \cdot \mathrm{L}^{-1} \mathrm{Mg}$. Magnesium effects on total and marketable fruit yield were mainly due to their influence on late fruit yield. There was little difference in fruit yield among treatments in early fruit production. High $\mathrm{Mg}$ increased fruit BER incidence at $150 \mathrm{mg} \cdot \mathrm{L}^{-1} \mathrm{Ca}$. Therefore, for a winter greenhouse tomato crop, the appropriate $\mathrm{Ca}$ and $\mathrm{Mg}$ concentrations for tomato production appear to be at 300 and 80 $\mathrm{mg} \cdot \mathrm{L}^{-1}$, respectively.

\section{Literature Cited}

Adams, P. 1994. Some effects of the environment on the nutrition of greenhouse tomatoes. Acta Hort. 366:405-416

Adams, P. and A.M. EL-Gizawy. 1988. Effect of calcium stress on the calcium status of tomatoes grown in NFT. Acta Hort. 222:15-22.

Adams, P. and R. Holder. 1992. Effects of humidity, $\mathrm{Ca}$ and salinity on the accumulation of dry matter and $\mathrm{Ca}$ by the leaves and fruit of tomato (Lycopersicon esculentum). J. Hort. Sci. 67:137-142.

DeGiglio, M.A. 2003. Growth of the fresh greenhouse tomato market in the USA. Acta Hort. 611:91-92.

De Kreij, C., J. Janse, B.J. van Goor, and J.D.J. van Doesburg. 1992. The incidence of cal- cium oxalate crystals in fruit walls of tomato (Lycopersicon esculentum Mill) as affected by humidity, phosphate and calcium supply. J. Hort. Sci. 67:45-50.

Den Outer, R.W. and W.H L. van Veenendaal. 1988. Gold speckles in tomato fruits (Lycopersicon esculentum Mill). J. Hort. Sci. 63:645-649.

Hao, X. 1995. The effects of UV-B radiation and its interactions with carbon dioxide and ozone on tomato (Lycopersicon esculentum Mill cv. New Yorker). PhD diss. Univ. Guelph, Guelph, Ont.

Hao, X and A.P. Papadopoulos. 2002. Growth, photosynthesis and productivity of greenhouse tomato cultivated in open or closed rockwool systems. Can. J. Plant Sci. 82:771-780.

Ho, L.C., D. J. Hand, and M. Fussell. 1999. Improvement of tomato fruit quality by calcium nutrition. Acta Hort. 481:463-468.

Holder, R. and K.E. Cockshull. 1990. Effect of humidity on the growth and yield of glasshouse tomatoes. J. Hort. Sci. 65:31-39.

Janse, J. 1988. Goudspikkels bij tomaat; een oplosbaar probleem. Groentn en Fruit 43:30-31.

Lopez, J., N. Tremblay, W. Voogt, S. Dube, and A. Gosselin. 1996. Effects of varying sulphate concentrations on growth, physiology and yield of the greenhouse tomato. Sci. Hort. 67:207-217.

Marcelis, L.F.M., E. Heuvelink, and J. Goudriaan. 1998. Modelling biomass production and yield of horticultural crops: A review. Sci. Hort. 74:83-111

NukayaA. and H. Hashimoto. 2000. Effects of nitrate, chloride and sulfate ratios and concentration in the nutrient solution on yield, growth and mineral uptake characteristics of tomato plants grown in closed rockwool system. Acta Hort. 512:165-172.

Ontario Ministry of Agriculture and Food-Fruit and Vegetable Inspection Branch. 1987. Greenhouse tomato grading and packing manual, from Regulation 378/90, the Farm Products Grades and Sales Act.

Ontario Ministry of Agriculture and Food. 2001. Publication 371: Growing greenhouse vegetables. Queen's Printers for Ontario, Ont., Can.

Papadopoulos, A.P. 1991. Growing greenhouse tomatoes in soil and in soilless media. Agr. Agri-Food Can. Publ. 1865/E.

Papadopoulos, A.P. and N.Liburdi. 1989. The Harrow fertigation manager $®$, a computerized multifertilizer injector. Acta Hort. 260:255-266.

Papadopoulos. A.P. and X. Hao. 2002. Interactions between nutrition and environmental condition in hydroponics, p. 411-443. In: D. Savvas and H. Passam (eds.). Hydroponic production of vegetables and ornamentals. Embryo Publ., Athens, Greece.

Paiva, E.A.S., R.A. Sampaio, and H.E.P. Martinez. 1998. Composition and quality of tomato frui cultivated in nutrient solutions containing different calcium concentrations. J. Plant Nutr. 21:2653-2661.

Saure, M.C. 2001. Blossom-end rot of tomato (Lycopersicon esculentum Mill) - A calcium- or stressrelated disorder? Sci. Hort. 90:193-208.

Sonneveld, C. 1987. Magnesium deficiency in rockwool-grown tomatoes as affected by climatic conditions and plant nutrition. J. Plant Nutr. 10:1591-1604

Sonneveld, S. and W. Voogt. 1991. Effects of $\mathrm{Ca}$-stress on blossom-end rot and Mg-deficiency in rockwool grown tomato. Acta Hort. 294:81-88

Voogt, W. and C. Sonneveld. 1997. Nutrient management in closed growing systems for greenhouse production, p. 83-102. In: E. Goto, K. Kurate, M. Hayashi, and S. Sase (eds.). Plant production in closed ecosystems. Kluwer Academic Publ, Dordrecht, The Netherlands. 